Abstracta Iranica

Revue bibliographique pour le domaine irano-aryen

Volume 32-33 | 2013

Comptes rendus des publications de 2009-2010

\title{
Saïd Amir Arjomand. After Khomeini. Iran Under His Successors
}

\section{Clément Therme}

\section{Q OpenEdition \\ 12 Journals}

\section{Édition électronique}

URL : http://journals.openedition.org/abstractairanica/41005

DOI : 10.4000/abstractairanica.41005

ISSN : 1961-960X

Éditeur :

CNRS (UMR 7528 Mondes iraniens et indiens), Éditions de l'IFRI

\section{Édition imprimée}

Date de publication : 1 décembre 2013

ISSN : 0240-8910

Référence électronique

Clément Therme, «Saïd Amir Arjomand. After Khomeini. Iran Under His Successors », Abstracta Iranica [En ligne], Volume 32-33 | 2013, document 445, mis en ligne le 01 juillet 2016, consulté le 26

septembre 2020. URL : http://journals.openedition.org/abstractairanica/41005 ; DOI : https://doi.org/ 10.4000/abstractairanica.41005

Ce document a été généré automatiquement le 26 septembre 2020.

Tous droits réservés 


\title{
Saïd Amir Arjomand. After Khomeini. Iran Under His Successors
}

\author{
Clément Therme
}

\section{RÉFÉRENCE}

Saïd Amir Arjomand. After Khomeini. Iran Under His Successors. Oxford/New York, Oxford University Press, 2009, 268 p.

1 Le principal argument de cet ouvrage est d'expliquer les évolutions politiques de la République islamique par le prisme révolutionnaire sans omettre le rôle des ruptures et des continuités constitutionnelles. Force est de constater que la démonstration de l'A. est convaincante même si elle prend le contre-pied des analyses considérant que la mort du dirigeant charismatique, l'Āyatollāh Homeynī (1989), signifiait la fin de la révolution. Il relève ainsi que les erreurs d'appréciation à propos des évolutions de l'ordre politique de la République islamique, après 1989, sont en partie liées à l'acceptation de l'hypothèse selon laquelle le processus révolutionnaire était alors arrivé à son terme. Cette critique apparaît particulièrement pertinente lorsque l'on envisage rétrospectivement l'enthousiasme pour le mouvement de réformes et de démocratisation du président Hầtamī (1997-2005).

2 L'A. dresse un tableau des trajectoires personnelles des principales politiques à partir d'un modèle mettant en évidence un parcours évolutif en trois temps : radicalité, pragmatisme puis réformisme. Ces trois temps ne sont pas des étapes automatiques des trajectoires politiques personnelles mais ils éclairent, par exemple, le parcours du président Hâatamì : un radical converti au réformisme au travers du pragmatisme. Plus largement, l'A. propose de distinguer trois catégories dans les factions de la République islamique : les modérés, les pragmatiques et les tenants de la ligne dure (hardliners). Il note que ces lignes de fracture ne sont pas figées mais en mouvement perpétuel. 
L'ouvrage est construit selon un plan chronologique distinguant les grandes phases des évolutions de l'ordre politique de la République islamique: 1979-1989, 1989-1997, 1997-2005, 2005-2009 et, après 2009. Enfin, au-delà de la nature autocratique du système politique de la République islamique, l'A. insiste sur la dimension néopatrimoniale du régime, qu'il qualifie de « monarchie cléricale ».

\section{AUTEURS}

\section{CLÉMENT THERME}

Paris 